\title{
ЗАСТОСУВАННЯ ВАКУУМНИХ ЙОННО-ПЛАЗМОВИХ ПОКРИТТІВ У ДЕРЕВООБРОБЛЕННІ
}

\begin{abstract}
Проаналізовано доцільність застосування вакуумних йонно-плазмових покриттів у деревообробленні. Розглянуто питання розподілу залишкових напружень по товщині покриття з TiN на дискових пилах. Встановлено, що найбільші напруження стиску, які забезпечують найвищу твердість і зносостійкість, $є$ у покриття завтовшки 5 мкм. Оптимальною $є$ тривалість процесу 30 хв. Результати досліджень процесу тертя індентора із інструментальної сталі Р6М5 з покриттям з ТіN за зразком із сосни показали, що застосування покриття дає змогу зменшити силу тертя на 60 \%. Наведено результати експериментів у виробничих умовах ДП "Стрийське лісове господарство" та ВАТ "Жидачівський целюлозно-паперовий комбінат" щодо зміцнення різальних зубців ланцюгів бензомоторних пилок ПЦУ-10 та болтів для кріплення ножів млина ST-660 паперового цеху та рафінерів гарячого помолу СВ-36, які контактують з технологічним середовищем. Завдяки нанесенню вакуумних йонно-плазмових покриттів із TiN, Ti-Ni-N, Ti + TiN, Ti-Ni-N + TiN, Mo-Ni-N pecypс роботи деталей збільшено в $1,3 \ldots 2,5$ раза. Зроблено висновок про те, що проблема застосування цих покриттів у деревообробленні $є$ актуальною і потребує подальших досліджень.
\end{abstract}

Ключові слова: залишкові напруження; товщина покриття; сила тертя; зносостійкість; технологічні середовища.

Вступ. Технологія вакуумного йонно-плазмового напилення є одним із найперспективніших способів поверхневого зміцнення інструменту, деталей та вузлів машин і технологічного оснащення. Вагомий внесок у розвиток наукових основ цієї технології зробили українські вчені. Зокрема, в Національному науковому центрі "Харківський фізико-технічний інститут" розроблено серію установок для йонно-плазмового напилення типу "Булат", які постійно вдосконалюються. Процеси, що відбуваються під час напилення, та властивості отриманих покриттів досліджено у численних наукових роботах провідних вчених інститутів Національної академії наук і закладів вищої освіти України.

Головними напрямами досліджень $є$ вивчення фізико-хімічних процесів під час перенесення матеріалу катоду на підкладку, плазмохімічних реакцій цього матеріалу з реактивним газом, фізико-механічних властивостей та експлуатаційних характеристик отриманих покриттів; вдосконалення конструкції установок для отримання багатокомпонентних покриттів, зменшення частки крапельної фази в плазмовому потоці, нанесення покриттів на габаритні деталі та внутрішні поверхні.

У більшості робіт з цієї проблематики досліджено підвищення ресурсу роботи металорізального інструмента, тому потребує більшої уваги висвітлення пи- тань, пов'язаних із характером взаємодії інструмента 3 цими покриттями в контакті з деревиною.

Матеріали і методи дослідження. Покриття наносили на установці "Булат-3T" 3 дотримуванням таких режимних параметрів (табл. 1). Визначення залишкових напружень проводили механічним методом, що грунтується на вимірюванні деформацій згину, які виникають під час пошарового знімання металу електрохімічним травленням по половині циліндра. Оцінку триботехнічних властивостей покриття здійснено для пари тертя "сталевий індентор - деревина (сосна)" на трибометрі ТМ-90. Циліндричний індентор діаметром 5 мм 3 конусом при вершині 3 радіусом його заокруглення 0,5 мм виготовлено зі сталі P6M5 3 покриттям 3 TiN. Зразки розміром $32 \times 16 \times 5$ мм виготовлено 3 деревини сосни в сухому стані (вологість $12 \%$ ) з поздовжнім і поперечним розміщенням волокон. Основні механічні характеристики зразків:

- границя міцності під час розтягу: вздовж волокон103 Мпа; поперек волокон - 5,4 Мпа;

- ударна в'язкість $-4,1 \cdot 10^{4}$ Дж/ $\mathrm{m}^{2}$;

- статична твердість поверхні:

а) торцевої - $28 \mathrm{MПа,}$

б) радіальної - 23,5 МПа,

в) тангенціальної - 24,5 МПа.

\section{Інформація про авторів:}

Гасій Олександр Богданович, канд. техн. наук, доцент, кафедра технології матеріалів та машинобудування.

Email: o.hasiy@gmail.com; https://orcid.org/0000-0001-7684-710X

Голубець Володимир Михайлович, д-р техн. наук, професор, завідувач кафедри технології матеріалів та машинобудування. Email: golubets.volodymyr@gmail.com

Степанишин Володимир Іванович, канд. техн. наук, доцент, кафедра технології матеріалів та машинобудування. Email: v.stepanyshyn@gmail.com

Цитування за ДстУ: Гасій О. Б., Голубець В. М., Степанишин В. І. Застосування вакуумних йонно-плазмових покриттів у деревообробленні. Науковий вісник НЛтУ України. 2019, т. 29, № 10. С. 75-77.

Citation APA: Hasiy, O. B., Holubets, V. M., \& Stepanyshyn, V. I. (2019). Application of vacuum ion-plasma coatings in woodworking. Scientific Bulletin of UNFU, 29(10), 75-77. https://doi.org/10.36930/40291014 
Випробування на трибометрі проведено за навантаження $0,3 \mathrm{H}$ і зворотньо-поступального руху сталевого індентора зі середньою швидкістю $0,02 \mathrm{~m} / \mathrm{c}$. Силу тертя $F m p$ фіксували при разовому проході індентора $\left(F m p_{1}\right)$ i після шести проходів контентора $\left(F m p_{6}\right)$. Переміщення індентора здійснювали за допомогою електродвигуна
Д-38Г ( $V=10000$ об/хв), який через редуктор плавно регулював швидкість індентора в межах $10 \ldots 500$ мм/хв. Навантаження індентора здійснювали спеціальними тягарцями через навантажувальний пристрій, що дало нам змогу ступенево змінювати навантаження на індентор від 0,02 до $0,5 \mathrm{H}$.

Табл. 1. Режими осадження вакуумних конденсатів

\begin{tabular}{|c|c|c|c|c|c|c|c|}
\hline \multirow{2}{*}{$\begin{array}{c}\text { Компоненти } \\
\text { покриття }\end{array}$} & \multicolumn{2}{|c|}{$\begin{array}{c}\text { Матеріал випаровувача і струм } \\
\text { дуги, А } \\
\end{array}$} & \multirow[t]{2}{*}{ Робочий газ } & \multirow[t]{2}{*}{ Тиск газу, Па } & \multirow{2}{*}{$\begin{array}{c}\text { Опорна напру- } \\
\text { га, В }\end{array}$} & \multirow{2}{*}{$\begin{array}{l}\text { Температура } \\
\text { підкладки, }{ }^{0} \mathrm{C}\end{array}$} & \multirow{2}{*}{$\begin{array}{c}\text { Товщина пок- } \\
\text { риття, мкм }\end{array}$} \\
\hline & I випаровувач & II випаровувач & & & & & \\
\hline $\mathrm{Ti}$ & $\mathrm{Ti} / 100$ & - & - & - & 150 & 350 & $5 \ldots 6$ \\
\hline Ti-N & $\mathrm{Ti} / 100$ & - & $\mathrm{N}_{2}$ & $0,4 \ldots 0,5$ & 150 & 350 & $5 \ldots 6$ \\
\hline Ti-Ni-N & $\mathrm{Ti} / 100$ & $\mathrm{Ni} / 170$ & $\mathrm{~N}_{2}$ & $0,4 \ldots 0,5$ & 150 & 400 & $5 \ldots 6$ \\
\hline Mo-Ni-N & $\mathrm{Mo} / 200$ & $\mathrm{Ni} / 100$ & $\mathrm{~N}_{2}$ & $0,3 \ldots 0,4$ & 170 & 450 & $6 \ldots 7$ \\
\hline
\end{tabular}

У корпусі трибометра на плоских пружинах кріпили зразок $з$ деревини, який переміщується разом із корпусом по напрямних, але під дією навантаженого індентора і сили тертя, що при цьому виникає, швидкість його руху сповільнюється. Плоскі пружини деформуються, величина їх деформації пропорційна силі тертя. Вимірявши величину деформації пружини, а відповідно і силу тертя, за допомогою швидкодіючого індуктивного датчика моделі 211, який подає електричні сигнали на самописець моделі Н-388-1П, фіксували силу тертя в процесі експерименту зі записом іiї на трибограму.

Результати дослідження та їх обговорення. Важливим питанням є дослідження розподілу залишкових напружень по товщині покриття. У роботі (Savchuk, 1984) показано, що ці напруження мають нелінійний характер зміни (табл. 2)

Табл. 2. Залишкові напруження у покриттях iз TiN, ГПа

\begin{tabular}{|c|c|c|c|}
\hline $\begin{array}{c}\text { Товщина пок- } \\
\text { риття, мкм }\end{array}$ & $\begin{array}{c}\text { Час напилення } \\
30 \text { хв }\end{array}$ & $\begin{array}{c}\text { Час напилення } \\
60 \text { хв }\end{array}$ & $\begin{array}{c}\text { Час напилення } \\
90 \text { хв }\end{array}$ \\
\hline 2 & $-1,7$ & $-1,4$ & $-1,1$ \\
\hline 5 & $-3,2$ & $-1,9$ & $-1,9$ \\
\hline 15 & $+1,6$ & $+1,4$ & $+1,2$ \\
\hline 20 & $+0,8$ & $+0,6$ & $+0,2$ \\
\hline
\end{tabular}

Результати досліджень показали, що чим менший час напилення, тим більший діапазон зміни величини залишкових напружень. Окрім цього, залишкові напруження зменшуються зі збільшенням товщини покриття. Тобто для досягнення напружень стиску порядку 3 ГПа, які сприяють підвищенню зносостійкості і твердості покриття, немає потреби збільшувати час його нанесення, що дає змогу істотно економити електроенергію. Отримані результати корелюють 3 висновками, отриманими під час нанесення покриттів на металорізальний інструмент (Andreev, 2005).

Результати досліджень триботехнічних характеристик інструментальної сталі Р6М5 з вакуумним йонноплазмовим покриттям $3 \mathrm{TiN}$ за використання в ролі контртіла зразків $з$ деревини сосни (Holubets, 2009) показали, що зі збільшенням кількості проходів індентора 3 одного до шести сила тертя як під час тертя вздовж волокон, так і поперек них зростає, тобто $F m p_{1}<F m p_{6}$ (табл. 3). Очевидно, що зі збільшенням кількості проходів відбувається неодноразова деформація зруйнованих волокон, внаслідок цього слід від індентора, який має вигляд ямки (рисунок), набуває сідлоподібної форми. Ця форма сприяє заглибленню індентора на певну глибину (на цій породі деревини вона становить 0,014...0,016 мм). Твердість покриття з TiN різко зростає порівняно з незміцненою сталлю Р6М5 $(7,6 \ldots 7,8$ проти 2,2..2,5 ГПа), що зменшує значення сили тертя, при цьому глибина лунки збільшується до 0,023...0,025 мм, тобто на $60 \%$.

Табл. 3. Результати триботехнічних досліджень пари тертя "сталь - суха деревина (сосна)" ( $V=0,02$ м/с; $P=0,3$ Н $)$

\begin{tabular}{|c|c|c|c|c|}
\hline \multirow{4}{*}{$\begin{array}{c}\text { Матеріал інден- } \\
\text { тора і тип пок- } \\
\text { риття }\end{array}$} & \multicolumn{4}{|c|}{ Напрямок волокон } \\
\hline & & & & \\
\hline & \multicolumn{4}{|c|}{ Сила тертя Fmp, H } \\
\hline & $F m p_{1}$ & $\mathrm{Fmp}_{6}$ & $F m p_{1}$ & $F m p_{6}$ \\
\hline Сталь Р6М5 & 0,07 & 0,075 & 0,08 & 0,085 \\
\hline P6M5 + TiN & 0,035 & 0,04 & 0,04 & 0,045 \\
\hline
\end{tabular}

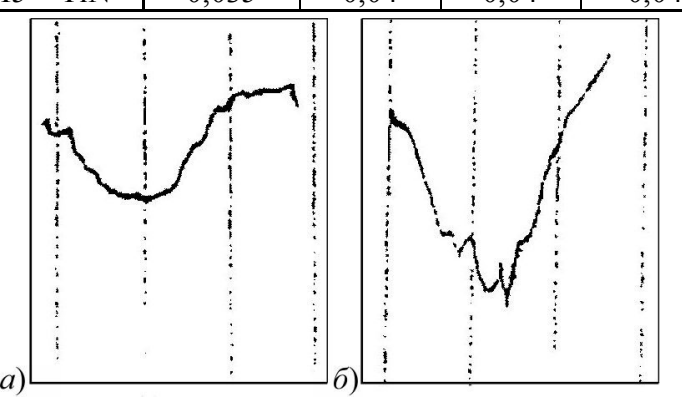

Рисунок. Профілограми, зняті зі зразків деревини після випробувань упродовж 1 хв при $\mathrm{P}=0,3 \mathrm{H} \mathrm{i} \mathrm{V}=0,02 \mathrm{~m} / \mathrm{c}$ (матеріал зразка - сосна, напрям волокон - вздовж): а) тертя в парі зі сталлю Р6M5; б) в парі зі сталлю P6M5 + TiN. Вертикальне збільшення - 1000, горизонтальне - 20

Ми провели натурні випробування інструментів i деталей 3 розробленими покриттями в умовах виробництва. На ДП "Стрийське лісове господарство" пройшли випробування бензомоторні пилки типу ПЦУ-10 з розробленими покриттями, нанесеними на різальні зубці ланцюгів, виготовлених із сталі $85 Х$ Ф. Всього зміцнено 15 ланцюгів. Встановлено, що ресурс роботи ланцюгів до перезаточування є таким:

- незміцнені - 30 м ${ }^{3}$ розкряжування деревини хвойних порід;

- 3 покриттям із Ti-Ni-N $-40 \mathrm{~m}^{3}$;

- 3 покриттям із $\mathrm{Ti}+\mathrm{Ti} \mathrm{N}-50 \mathrm{~m}^{3}$;

- 3 покриттям із Ti-Ni-N + Ti N -70 м $^{3}$.

Отже, ресурс роботи пиляльних ланцюгів збільшився в $1,3 \ldots 2,3$ раза порівняно з незміцненими. На ВАТ "Жидачівський целюлозно-паперовий комбінат" випробувано покриття на болти M16 зі сталі 3 для кріплення ножової гарнітури млина ST-660 паперового цеху паперово-картонного виробництва бурого потоку, які працюють в середовищі макулатури та півцелюлози високого виходу із вмістом глинозему на основі $\mathrm{Al}_{2} \mathrm{O}_{3}$. Всього зміцнено 18 болтів. Встановлено, що ресурс їх роботи є таким:

- не зміцнені - 3 місяці;

- 3 покриттям із Ті N - 4 місяці; 
- $з$ покриттям із Ti-Ni-N - 4,5 місяці;

- 3 покриттям із Ti-Ni-N + Ti N - 6 місяців;

- 3 покриттям із $\mathrm{Ti}+\mathrm{Ti} \mathrm{N}-7,5$ місяців.

Отже, ресурс роботи болтів збільшився в 1,3..2,5 раза. На цьому ж підприємстві випробувано покриття на болти M16 зі сталі 3 для кріплення ножів рафінерів гарячого помолу CB-36, які працюють у середовищі варильного лугу целюлозного заводу, що містить $75 \%$ $\mathrm{NaOH}$ I $25 \% \mathrm{Na}_{2} \mathrm{~S}$. Встановлено, що ресурс їх роботи $\epsilon$ таким:

- не зміцнені - 4 місяці;

- 3 покриттям із Ti-Ni-N - 6 місяців;

- 3 покриттям із Mo-Ni-N - 7 місяців;

- $з$ покриттям із Ті N-9 місяців.

Ресурс роботи болтів збільшився в 1,5...2,25 раза.

Висновок. Результати проведених досліджень засвідчують, що нанесення вакуумних йонно-плазмових покриттів істотно підвищує ресурс роботи дереворізального інструмента та деталей, що працюють у техно- логічних середовищах, тому проблема їх застосування в деревообробленні є актуальною і потребує подальших досліджень.

\section{References}

Andreev, A. A., Sablev, L. P., Shulaev, V. M., \& Grigorev, S. N. (2005). Vacuum arc devices and coatings: Monograph. Kharkiv: NSC KPTI, 236 p. [In Russian].

Holubets, V. M., Hasiy, O. B., \& Bilous, O. V. (2009). Wear resistance of a vacuum ion-plasma coating in conditions of dry friction in contact with wood. Efficiency of realization of scientific, resource and industrial potential in modern conditions: Materials IX International Industrial Conference, (pp. 116-118). Slavsk, February 913, 2009. Kyiv. [In Ukrainian].

Savchuk, Ja. I. (1984). Increase of resistance of circular saws in the processing of chipboards with a coating of titanium nitride. Abstract of Candidate Dissertation for Technical Sciences (05.06.02 - Machines and Mechanisms for Forestry, Logging, Forestry and Woodworking Industries). Lviv, 24 p. [In Russian].

O. B. Hasiy, V. M. Holubets, V. I. Stepanyshyn

Ukrainian National Forestry University, Lviv, Ukraine

\section{APPLICATION OF VACUUM ION-PLASMA COATINGS IN WOODWORKING}

The article analyzes the feasibility of using vacuum ion-plasma coatings in wood processing. The problems of the distribution of residual stresses in the thickness of the coating of TiN on circular saws were considered. These stresses are defined to be non-linear changes. The greatest compressive stresses, which provide the highest hardness and wear resistance, were found in a coating with thickness of $5 \mu \mathrm{m}$. With an increase in the duration of the evaporation process, the compressive stresses decrease. The optimal process duration is 30 minutes, which allows significant energy saving. The results of the study of the friction of the indenter of R6M5 instrumental steel coated with TiN on a sample of pine showed that with an increase in the number of passes of the indenter from one to six, the friction force both during friction along the fibres and across them increases. With an increase in the number of passes, repeated deformation of the destroyed fibres occurs, as a result, the trace from the indenter acquires a saddle shape, resulting in the indenter deepening to a depth ranging from 0.014 to $0.016 \mathrm{~mm}$. The use of TiN coating reduces friction force by $60 \%$. The authors provide the results of experiments in the production conditions of Stryisky Forestry State Enterprise and Zhydachiv Pulp and Paper Mill OPJC for strengthening the cutting teeth of chains of PTsU-10 gasoline saws and ST-660 bolts for fastening knives of the mill and SV-36 hot grinder in contact with the technological fluid. Due to the application of TiN, Ti-Ni-N, Ti + TiN, Ti-Ni-N + TiN, Mo-Ni-N vacuum ion-plasma coatings, the work life of the parts is increased from 1.3 to 2.5 times. Thus, we have come to the conclusion that the problem of applying these coatings in woodworking is relevant and requires further research.

Keywords: residual stresses; coating thickness; friction force; wear resistance; technological fluids. 